PERM JOURNAL OF PETROLEUM AND MINING ENGINEERING

ВЕСТНИК ПНИПУ. ГЕОЛОГИЯ. НЕФТЕГАЗОВОЕ И ГОРНОЕ ДЕ ЛО

ISSN 2224-9923

Volume / Tом 20 №2, 2020

http://vestnik.pstu.ru/geo/

UDC 622.276.(470.53)

Article / Статья

(C) PNRPU / ПНИПУ, 2020

\title{
EXPERIENCE OF OILFIELD DEVELOPMENT IN PERM KRAI USING HORIZONTAL WELLS
}

\section{Roman A. Zaitcev, Aleksei V. Raspopov}

PermNIPIneft branch of LUKOIL-Engineering LLC in Perm (3a Permskaya st., Perm, 614015, Russian Federation)

\section{ОПЫТ РАЗРАБОТКИ МЕСТОРОЖДЕНИЙ ПЕРМСКОГО КРАЯ ГОРИЗОНТАЛЬНЫМИ СКВАЖИНАМИ}

\section{P.А. Зайцев, А.В. Распопов}

Филиал ООО «ЛУКОЙЛ-Инжиниринг» «ПермНИПИнефть» в г. Перми (614015, Россия, г. Пермь, ул. Пермская, 3a)

Received / Получена: 20.02.2020. Accepted / Принята: 15.04.2020. Published / Опубликована: 15.06.2020

\section{Key words:}

geological and physical

characteristics, carbonate

reservoir, terrigenous reservoir reserves, deposit, oilfield development, drilling, horizontal wells, directional wells, small diameter, oil output, operation, production, asset value.

\section{Ключевые слова} геолого-физическая характеристика, карбонатный коллектор, терригенный коллектор, запасы, залежь, месторождение, разработка, бурение, горизонтальные скважины, наклоннонаправленные скважины, малый диаметр, дебит нефти, эксплуатация, добыча, ценность актива.
Hydrocarbon reservoir engineering has a top priority to achieve the highest possible value of the cost-effective oil recovery factor. Structural deterioration of residual oil reserves and inevitable development of hard-to-recover reserves require new effective technologies and engineering solutions. Today, there is a tendency to replace the standard size well drilling technologies (including vertical, directional, horizontal, multilateral wells) and standard size dual completion equipment usage by slim-hole drilling technologies. In Perm Krai fields, more than 385 horizontal wells have been drilled, while $3.4 \%$ of them, i.e. 13 wells, have a small diameter. The conducted well operation analysis shows that the effectiveness of the horizontal well operations in a number of instances is significantly lower than the potential one. This leads to a deteriorated economic performance of reservoir developments, and, eventually, to asset value reductions. Perhaps, the main reason of low effectiveness of the horizontal well operations lies is an insufficient understanding of geological and physical conditions of their successful operations. It has become obvious that drilling horizontal wells in reservoirs with high compartmentalization, low net oil thickness, and decreased hydrodynamic connectivity to the edge water zone offer a low level of performance. Productivity tends to decrease to average output values of directional wells. Therefore, the problem of choosing a well design and its direction in specific geological and physical conditions is highly relevant.

В настоящее время при проектировании разработки месторождений углеводородного сырья приоритетом является достижение максимально возможного и экономически рентабельного коэффициента извлечения нефти. Ухудшение структуры остаточных запасов нефти, необходимость вовлечения трудноизвлекаемых запасов в разработку привели к поиску новых эффективных технологических решений в проектировании. На сегодняшний день осуществляется поэтапный переход (замена) технологии бурения вертикальных, наклонно направленных (в том числе горизонтальных, многозабойных) скважин, применения оборудования одновременно раздельной эксплуатации скважин в стандартном диаметре на малый диаметр.

На месторождениях Пермского края пробурено более 385 горизонтальных скважин, из которых 3,4 \% (13 скважин) составляют скважины малого диаметра. Проведенный анализ эксплуатации скважин показывает, что эффективность использования горизонтальных скважин в ряде случаев оказывается существенно ниже потенциальной и, ухудшая экономические показатели разработки объекта, в конечном счете приводит к снижению ценности актива. Возможно, главной причиной низкой эффективности использования горизонтальных скважин является недостаточное понимание геолого-физических условий для их эксплуатации. Накопленный опыт бурения горизонтальных скважин в коллекторах с высокой расчлененностью, малыми значениями эффективных нефтенасыщенных толщин, ухудшенной гидродинамической связью с законтурной областью показал их низкую успешность: отмечается динамика снижения продуктивности до средних значений дебитов наклонно направленных скважин. В связи с этим актуальным становится вопрос выбора конструкции скважины и ее направленности в конкретных геолого-физических условиях.

Roman A. Zaitcev - Lead Engineer (tel.: +7 91970133 61, e-mail: Roman.Zajtsev@pnn.lukoil.com). The contact person for correspondence.

Aleksei V. Raspopov (Scopus ID 30267829600) - PhD in Engineering, Deputy Director of the Branch for Scientific Work in the Area of Field Development (tel.: +007342 21982 92, e-mail: aleksej.raspopov@pnn.lukoil.com).

Зайцев Роман Александрович - ведущий инженер (тел.: +7 91970133 61, e-mail: Roman.Zajtsev@pnn.lukoil.com). Контактное лицо для переписки. Распопов Алексей Владимирович - кандидат технических наук, заместитель директора филиала по научной работе в области разработки месторождений (тел.: +007 34221982 92, e-mail: aleksej.raspopov@pnn.lukoil.com). 


\section{Introduction}

Development of oilfields in Perm Krai started in 1929. Oil production peak in 1976 was followed by a sharp decrease (almost by three times) to the minimum level in 1994. A gradual growth of annual recoveries (starting from 1995) resulted in a two-fold increase of oil production by 2019. Factor analysis of growth shows that the basic production relative to the year of the historic minimum as of January $1^{\text {st }}, 2020$ amounts to only onefourth of the entire oil production. Bringing into service deposits of produced fields and discovery of new ones would help stabilize oil production at the level of the historic minimum. Use of state-of-the art production drilling technologies in combination with extensive replications of new geological and technical activities based on the results of successful pilot production works (PPW) helped ensure the output growth in the old oil producing region almost by $40 \%$ (Fig. 1).

As of January $1^{\text {st }}, 2020$, the majority of producing fields in Perm Krai with high and medium porosity and permeability (P\&P) had high recovery rates of oil reserves [1].

In the current structure of residual recoverable reserves (RRR) in Perm Krai oilfields, ineffective reserves constitute $61 \%$ (Fig. 2). This category includes oil deposits with low permeability (less than $0.05 \mu \mathrm{m}^{2}$ ), high viscosity (more than $30 \mathrm{mPa} \cdot \mathrm{s}$ ) and low net oil thicknesses (less than $2 \mathrm{~m}$ ).

It is obvious that over time, the structure of residual recoverable oil reserves deteriorates, necessitating the need for search, testing and implementation of new technologies for involvement of hard-to-recover reserves into production operations. If we consider structures of cumulative oil production since 1994, it is obvious that the major share of oil production ( $88 \%$ ) is associated with the old assets, i.e. mature fields. Many of Perm Krai fields are at the third stage of development $(66.1 \%)$ and have the largest residual recoverable reserves.
It became possible to increase oil production volumes in the conditions of annually deteriorating geological conditions due to activities in the following areas [2-7]:

- cost reduction due to the use of lightweight structure of wells, use of dual completion systems for several strata, side tracking

- implementation of new technologies for oil production stimulation (formation hydraulic fracture, self-diverting acid compounds, radial drilling, etc.)

- discovery of new oil deposits, additional exploration of fields (seismic exploration works using 3D method, exploration and prospecting drilling).

Lightweight well structures in Perm Krai oilfields have been used since 2010. At that time, cost reduction from a standard diameter directional well (DW) amounted to $8 \%$ [8-11]. In 2012-2013, this technology started to be commercially implemented, followed by the smallbore drilling technology to horizontal and multibranch wells. Empirical knowledge, as well as experience of Tatneft PJSC (2018-2019) through the use of reduced casing string diameters, use of a drilling rig with a smaller lifting capacity and implementation of a series of technical and technological solutions make it possible to reduce well construction costs up to $50 \%$ (upper development reservoirs), compared to standard diameter wells (168 mm) [12-17].

\section{Horizontal Wells in Perm Krai Oilfields}

Presently, great experience has been gathered concerning construction and operation of horizontal wells in both standard and small diameter categories [18-22]. Initial outputs of horizontal wells are usually times larger than outputs of vertical (directional) wells in the same geological and physical conditions [23, 24]. In Perm Krai fields, more than 385 horizontal wells have been drilled. The most intense growth of production drilling (PD) of horizontal wells is observed since 2010 . The majority of horizontal wells $(82 \%)$ are drilled in carbonate reservoirs (Fig. 3).

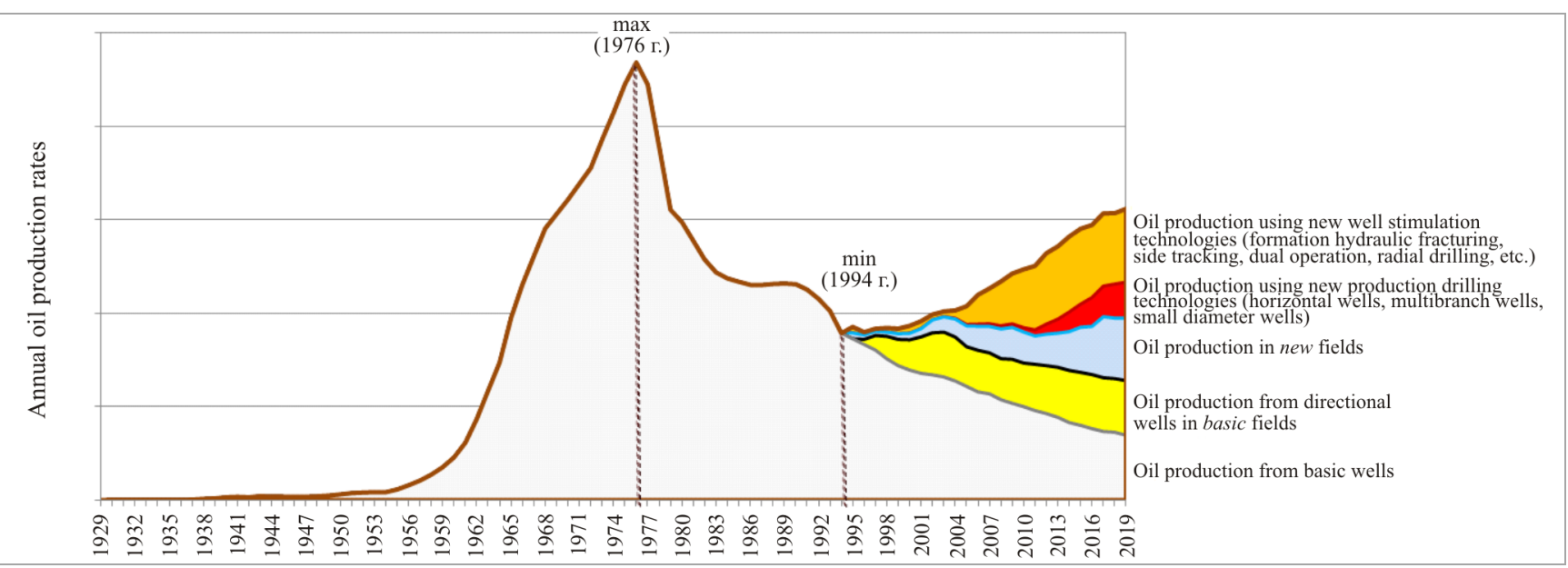

Fig. 1. Oil production dynamics in Perm Krai 


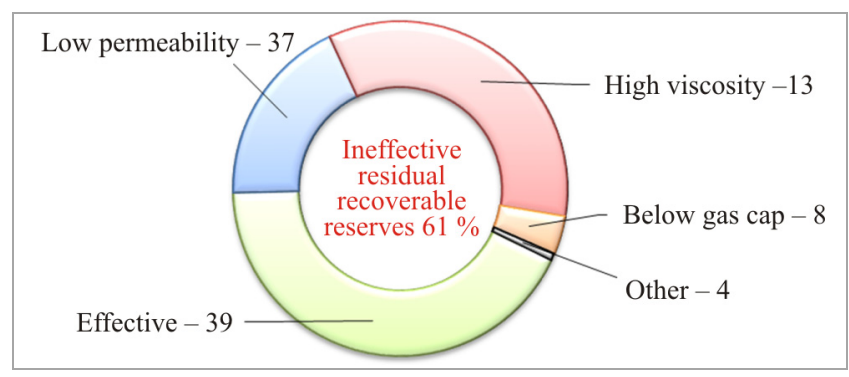

Fig. 2. Structure of residual recoverable reserves in Perm Krai oilfields, \%

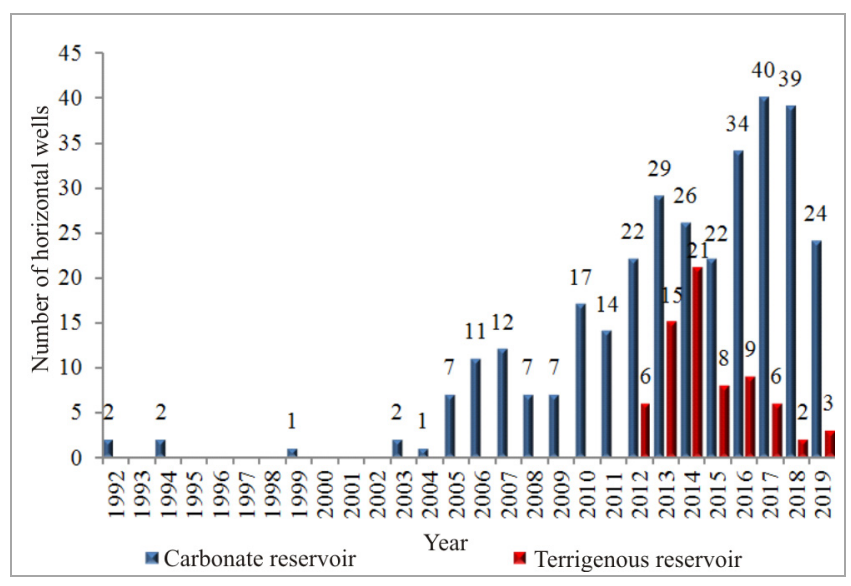

Fig. 3. Horizontal well drilling dynamics in Perm Krai oilfields

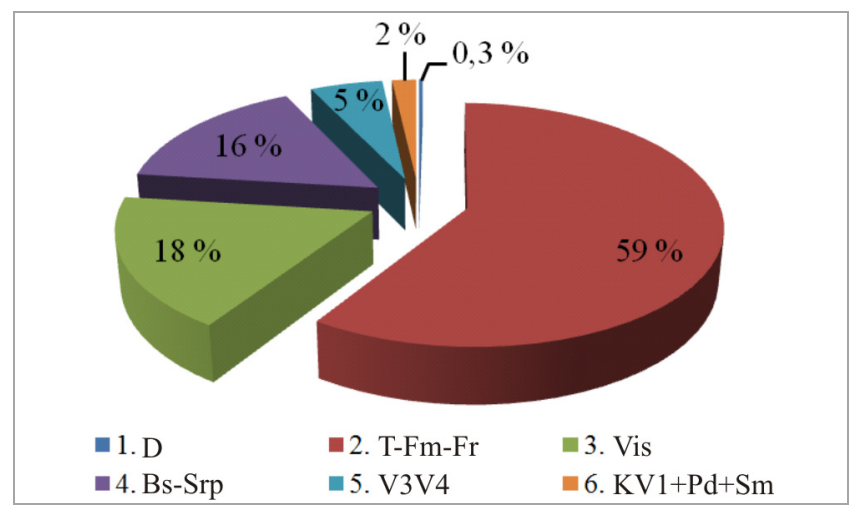

Fig. 4. Distribution of horizontal wells by development reservoirs. D shows Devonian deposits; T-Fm-Fr Tournaisian - Famennian - Frasnian deposits; V shows Visean deposits; Bs-Srp - Baskirian-Serpukhovian deposits; V3V4 - Vereiskian deposits; KV1+Pd+Sm - Kashirskian-

Vereiskian + Podolskian + Sakmarian deposits

Extensive drilling of horizontal wells for development of upper reservoirs (Bs, Srp, $\mathrm{V}_{3} \mathrm{~V}_{4}, \mathrm{KV}_{1}$ ) started since 2012. As of January $1^{\text {st }}$, 2020, upper development reservoirs accounted for $23 \%$ of the total amount of drilled horizontal wells. In less than ten years (2011-2020), the slim-hole drilling technology started to be used in Perm Krai fields, in Baskirian and Vereiskian development reservoirs with various types of completion (directional, including horizontal and

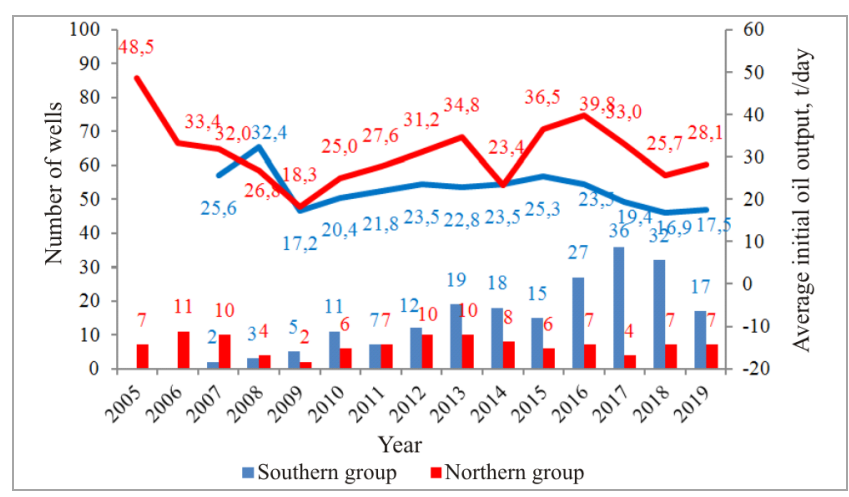

Fig. 5. Dynamics of average initial outputs of wells produced from the new horizontal wells in the carbonate reservoir ranged by territory

multibranch wells). Distribution of the horizontal wells across the development reservoirs is shown in Fig. 4.

Effectiveness of HW use is often far below the potential one, which has a negative impact on economic performance indicators of the reservoir development and, eventually, leads to an asset value reduction. The conducted analysis of HW drilling shows that the main reason of their low effectiveness is an insufficient understanding of geological and physical operation conditions [25-35].

Studies [36-46] outline that the success of HW drilling and operation is determined by costeffectiveness of the development method and a correct reservoir selection, a comprehensive study of formation geological and physical characteristics. It is also notable that HWs often fail to reach their intended performance: the actual output is below the plan, the produced fluid watercut grows rapidly, the share of producing intervals decreases, etc. Therefore, the problem of choosing a well direction profile in specific geological and physical conditions is highly relevant.

In terms of territory, Perm Krai oilfields can be provisionally divided into two groups: northern and southern. These groups of fields have different geological and physical characteristics and, as a consequence, well production capacities. Productivity of wells drilled in the reservoirs belonging to the northern group of oilfields is usually higher than that of the southern group. Dynamics of average initial oil outputs from HWs in carbonate reservoirs and ranging by territory for the period of 2005-2019 ( $80 \%$ of all the drilled HWs were commissioned for production) are shown in Fig. 5, whereas the main geological and physical parameters of these deposits are provided in the table.

The experience of drilling wells with various types of completion in the southern group of fields to upper development reservoirs helped adjust certain project solutions for a number of such reservoirs, since they contain the major part of residual recoverable reserves, 
Geological and physical characteristics of carbonate reservoirs in Perm Krai oilfields

\begin{tabular}{|c|c|c|c|c|c|c|}
\hline \multirow{2}{*}{ Parameter } & \multicolumn{2}{|c|}{ T-Fm reservoir } & \multicolumn{2}{|c|}{ Bs reservoir } & \multicolumn{2}{|c|}{$\mathrm{V}_{3} \mathrm{~V}_{4}$ reservoir } \\
\hline & Southern & Northern & Southern & Northem & Southern & Northem \\
\hline Permeability, mD & $1-1420$ & $2-647$ & $22-698$ & $9-123$ & $17-605$ & - \\
\hline Porosity, $\%$ & $7-15$ & $8-17$ & $14-16$ & $9-14$ & $12-20$ & - \\
\hline Average net oil thickness, $\mathrm{m}$ & $2.0-13.4$ & $4.5-30.2$ & $2.4-7.4$ & $4.4-15.9$ & $1-3.9$ & - \\
\hline Compartmentalization & $3.0-19.0$ & $6.0-41.4$ & $3.5-17.7$ & $5.4-29.9$ & $1.0-9.3$ & - \\
\hline Sandiness & $0.007-0.74$ & $0.08-0.45$ & $0.22-0.40$ & $0.15-0.62$ & $0.2-0.3$ & - \\
\hline
\end{tabular}

and pose the highest risk for the asset, because a wrong choice of a well design can significantly reduce its asset value. For instance, in Batyrbayskoye field, the experience of $\mathrm{HW}$ drilling in reservoirs belonging to Bs and $\mathrm{KV}_{1}$ in the inferior geological and physical conditions (high compartmentalization, low permeability and oil mobility) demonstrated their low effectiveness and helped adjust the production drilling program by changing well profile in its own reservoirs and their analogues.

\section{HW Drilling Experience in Batyrbayskoye Field}

In 2017-2018, in the scope of pilot production works (PPW) at Bs reservoir in the western part of Asulskoye uplift (Fig. 6), three producing horizontal wells (Nos. 1203, 1207, 1206) and one directional well (No. 1205) were drilled. Production drilling was performed in the previously uninvaded part of the deposit, with net oil thicknesses exceeding $4 \mathrm{~m}$. Initial outputs varied from 8.3 to 12.2 t/day for oil and 11 to $18.2 \mathrm{~m}^{3} /$ day for liquid. Despite the start of injection (well No. 1205) simultaneously with commissioning of the producing wells, productivity reduction was observed during operation in all wells. As of today, oil outputs range within 2.2-7.7 $\mathrm{t}$ /day for oil and $5-10 \mathrm{~m}^{3} /$ day for liquid. An average water intake of the injection well No. 1205 amounted to $25 \mathrm{~m}^{3} /$ day. Most probably, the well output reduction is related to the inferior hydrodynamic connectivity between the recovery and injection zones caused by geological and physical properties of the reservoir (high compartmentalization, low permeability and mobility).

Reduction of productivity may also be related to a high initial recovery from the wells, which is not typical for this development reservoir: nearly all producing wells have low outputs, $70 \%$ is operated with oil outputs up to $2 \mathrm{t}$ /day. As an instance, Fig. 7 shows the basic indicators descriptive of operation of production well No. 1203.

Based on the actual well operation in deposits with similar geological and physical characteristics (GPC), in the course of preparation of a project technology document for Baklanovskoye field in 2018, a

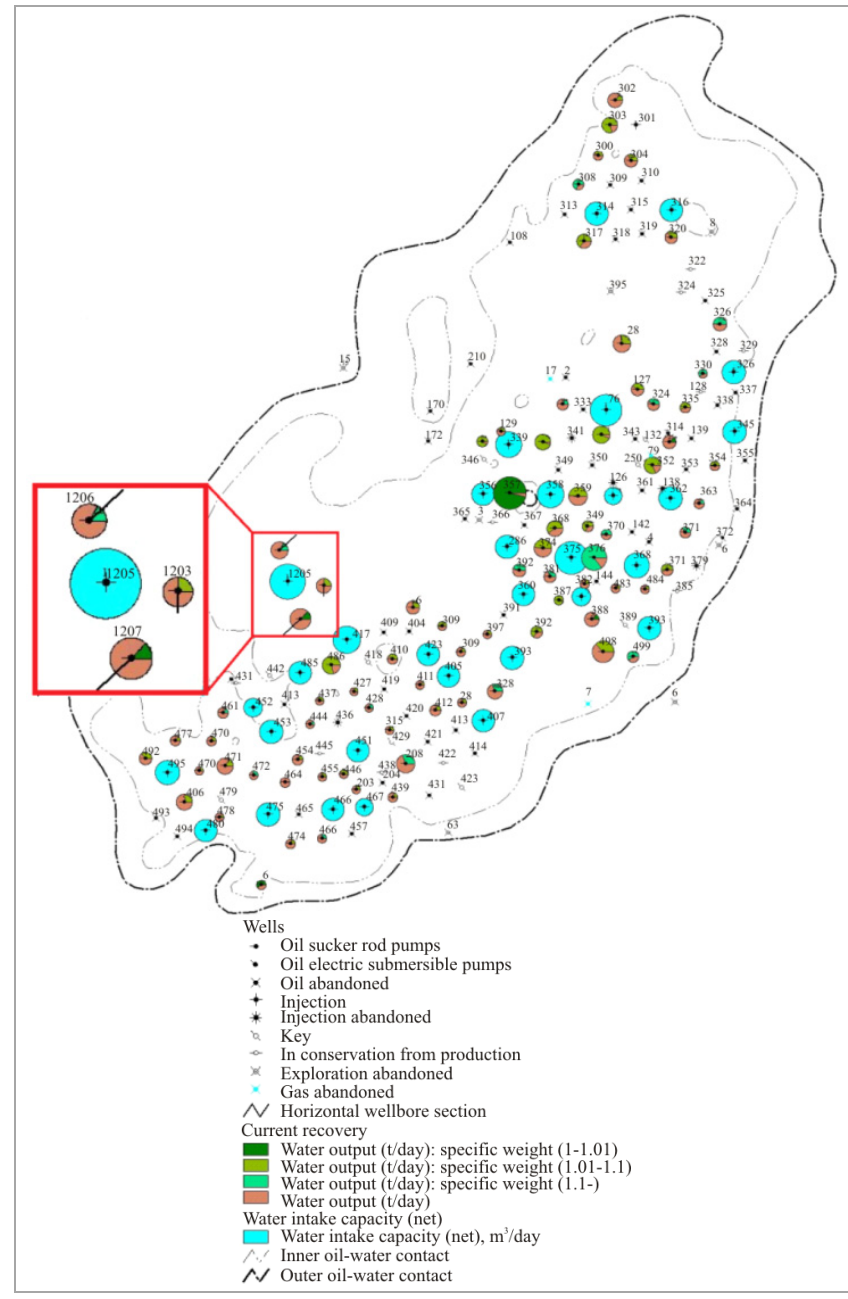

Fig. 6. Current recovery map from Bs reservoir of Asulskoye uplift of Batyrbayskoe field with PPW focus

justification was made to change the well profile from horizontal to directional. The previous project document dating back to 2008 envisaged involvement of large deposit areas in $\mathrm{Bs}$ and $\mathrm{V}_{3} \mathrm{~V}_{4}$ reservoirs by drilling horizontal wells with a standard diameter, a three-row well arrangement, and $350 \times 350 \mathrm{~m}$ grid. Since the project solutions did not meet the company profitability criteria, production drilling was not performed. In 2107, after test drilling of small diameter horizontal wells in Perm Krai fields in the course of industry development program preparation for Baklanovskoye field, the standard size 


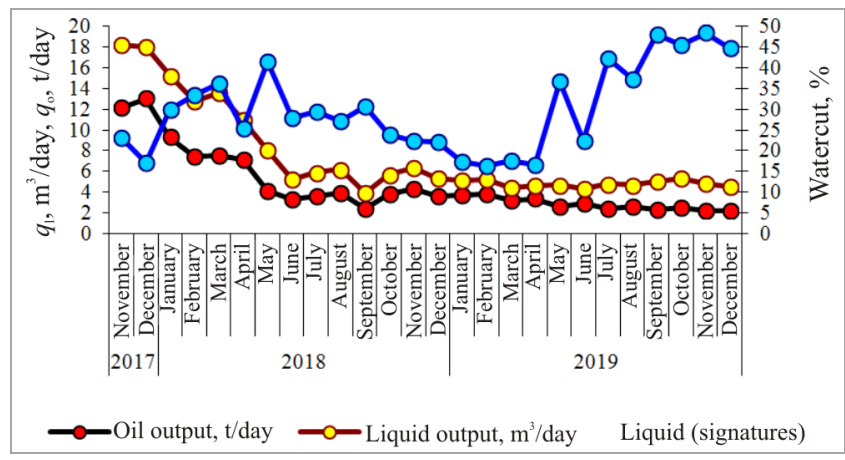

Fig. 7. Main operating indicators of horizontal well No. 1203 in Batyrbayskoye field (Bs reservoir)

well drilling technology was eventually substituted with the slim-hole drilling technology. Consequently, during project document preparation in 2018, scenarios with different well designs were considered. The slim-hole directional drilling technology has shown an increase of NPV up to $30 \%$ versus the the slim-hole horizontal drilling technology. According to the approved scenario, more than 30 wells were actually drilled at the field, 17 producing wells were commissioned, with oil outputs from 6.2 to $13.6 \mathrm{t} /$ day.

\section{Conclusion}

During the last 26 years, implementation of new production drilling technologies and oil production stimulation methods helped increase annual oil production outputs in the old oil producing region by almost $40 \%$.

For the horizontal wells drilled in the reservoirs with high compartmentalization and low net oil thicknesses, the productivity reduction dynamics is more pronounced. The productivity reduction to average values of the directional well outputs in the same reservoirs has been identified.

The experience of well drilling with various structures and directional profiles in identical geological and physical conditions requires determining the selection criteria of a certain method of well completion, which has a significant impact on the asset value.

\section{References}

1. Raspopov A.V., Kazantsev A.S., Antonov D.V. Vliianie monitoringa razrabotki na povyshenie effektivnosti ekspluatatsii neftianykh mestorozhdenii Permskogo kraia [The influence of development monitoring on oilfield exploration effectivness on the Perm Territory]. Neftianoe khoziaistvo, 2012, no. 6, pp. 58-61.
2. Voevodkin V.L., Chertenkov M.V. Novye tekhnologii v kompanii "LUKOIL": ot prostogo k slozhnomu [New Technologies in LUKOIL: from Simple to Complicated]. Neftianoe khoziaistvo, 2019, no. 8, pp. 62-66.

3. Kravets M.Z. Osobennosti proektirovaniia ploskikh i prostranstvennykh traektorii skvazhin i bokovykh stvolov [Design features of flat and spatial trajectories of wells and sidetracks]. Inzhener-neftianik, 2016, no. 2, pp. 42-47.

4. Lakupchik A.V., Solianov S.A., Mavletdinova M.G. Kliuchevye osobennosti tekhnologii provedeniia kompleksnoi obrabotki prizaboinoi zony na gorizontal'nykh mnogozaboinykh gazokondensatnykh skvazhinakh [Key features of technologies for integrated treatment of the bottom-hole zone in horizontal multilateral bottom-hole gas condensate wells]. Geologiia, geofizika $i$ razrabotka neftianykh $i$ gazovykh mestorozhdenii, 2019, vol. 333, no. 9, pp. 58-61.

5. Martiushev D.A. Laboratornye issledovaniia kislotnykh sostavov dlia obrabotki kollektorov, kharakterizuiushchikhsia razlichnoi karbonatnost'iu i strukturoi pustotnogo prostranstva gornykh porod [Laboratory studies of acid compositions for treating reservoirs characterized by different carbonate and rock voids structure]. Izvestiia Tomskogo politekhnicheskogo universiteta. Inzhiniring georesursov, 2018, vol. 329, no. 4, pp. 6-12.

6. Yue-tian LIU Methodology for horizontal well pattern design in anisotropic oil reservoirs. Petroleum Exploration and Development, 2008, vol. 35, iss. 5, pp. 619-624.

7. Yue Qiansheng, Liu Shujie, Xiang Xingjin. Drilling fluid technology for horizontal wells to protect the formations in unconsolidated sandstone heavy oil reservoirs. Petroleum Exploration and Development, 2010, vol. 37, iss. 2, pp. 232-236.

8. Voevodkin V.L., Raspopov A.V., Muzhikova L.N., Kondrat'ev S.A. Primenenie novykh tekhnologicheskikh reshenii $\mathrm{v}$ oblasti razrabotki na mestorozhdeniiakh OOO "LUKOIL-PERM"' [Application of new technological solutions in the field of oil \& gas development in the oilfields of LUKOILPERM LLC"]. Neftianoe khoziaistvo, 2012, no. 12, pp. 104-106.

9. Voevodkin V.L., Liadova N.A., Okromelidze G.V., Meshcheriakov K.A., Suntsov S.V., Mal'kov Iu.V. Opyt i perspektivy stroitel'stva skvazhin malogo diametra na mestorozhdeniiakh OOO "LUKOIL-PERM" [Experience and prospects of slim hole construction on LUKOILPERM oilfields"]. Neftianoe khoziaistvo, 2018, no. 12, pp. 98-102.

10. Meshcheriakov K.A., Iatsenko V.A., Il'iasov S.E., Okromelidze G.V. Burenie skvazhin malogo diametra kak sposob snizheniia zatrat pri stroitel'stve 
ekspluatatsionnykh i razvedochnykh skvazhin [Small diameter wells drilling as the method to reduce costs during construction of operation and exploratory wells]. Territoriia NEFTEGAZ, 2013, no. 10, pp. 62-65.

11. Meshcheriakov K.A., Okromelidze G.V., Iatsenko V.A., Fefelov Iu.V., Suntsov S.V., Mal'kov Iu.V. Rezul'taty stroitel'stva pervoi mnogozaboinoi skvazhiny malogo diametra v PAO "LUKOIL" [The results of construction of the first small diameter multilateral well in LUKOIL PJSC)]. Neftianoe khoziaistvo, 2018, no. 10, pp. 47-49.

12. Tarasov A.E., Starosvetskov V.V. Optimizatsiia protsessa geologicheskogo soprovozhdeniia bureniia gorizontal'nykh skvazhin na primere mestorozhdeniia imeni V.N. Vinogradova [Optimization of process of geological support of horizontal wells drilling at the fields named after V.N. Vinogradov]. Burenie $i$ neft', 2017, no. $7-8,61 \mathrm{p}$.

13. Taziev M.Z., Krotkov I.I., Garaev R.R., Sinchugov N.S., Osipov R.M., Asliamov A.I. Problemy $\mathrm{i}$ innovatsionnye resheniia pri burenii skvazhin malogo diametra [Problems and innovative solutions when drilling small diameter wells]. Neftepromyslovoe delo, 2011, no. 9, pp. 34-38.

14. Yaqiang CHEN, Longxin MU, Jianying ZHANG, Guanghua ZHAI, Huiying ZHAI. Horizontalwellinflow performance relationship in foamy heavy oil reservoirs. Petroleum Exploration and Development, 2013, vol. 40, iss. 3, pp. 389-393.

15. Wang H., Liao X., Zhao X. Study of tight oil reservoir flow regimes in different treated horizontal well. Journal of the Energy Institute, 2015, vol. 88, iss. 2, pp. 198-204.

16. Hou Jian, Zhou Kang, Zhao Hui, Kang Xiaodong, Zhang Xiansong. Hybrid optimization technique for cyclic steam stimulation by horizontal wells in heavy oil reservoir. Computers \& Chemical Engineering, 2016, vol. 844, pp. 363-370.

17. Junjun C., Yonggang D. Study on temperature distribution along wellbore of fracturing horizontal wells in oil reservoir. Petroleum, 2015, vol. 1, iss. 4, pp. 358-365.

18. Starosvetskov V.V., Kashnikov O.Iu. Osobennosti geologicheskogo soprovozhdeniia bureniia gorizontal'nykh skvazhin V slozhno-postroennykh kollektorakh (na primere mestorozhdeniia imeni V.N. Vinogradova [Features of geological support for drilling horizontal wells in complex-built reservoirs (for example, the field named after V.N. Vinogradov]. Geologiia, geofizika i razrabotka neftianykh i gazovykh mestorozhdenii, 2017, no. 2, pp. 43-49.

19. Kiselev V.M., Kinsfator A.R., Boikov O.I. Prognoz optimal'nykh napravlenii gorizontal'nykh stvolov dlia razrabotki Iurubcheno-Tomokhovskogo mestorozhdeniia [The forecast of the optimal directions of horizontal shafts for the development of the YurubchenoTomokhovskoye field]. Vestnik Permskogo natsional'nogo issledovatel'skogo politekhnicheskogo universiteta. Geologiia. Neftegazovoe i gornoe delo, 2015, vol. 14, no. 15 , pp. $20-27$.

20. Sadykov R.Sh., Ibragimova G.G. Optimizatsiia razrabotki uchastkov verkhnikh gorizontov skvazhinami malogo diametra $\mathrm{s}$ gorizontal'nym okonchaniem [Optimization of development of upper horizons sections by small diameter wells with a horizontal tail-end]. Neftepromyslovoe delo, 2016, no. 9, pp. 58-61.

21. Ashrafian M.O., Krivoshei A.V. Sovershenstvovanie tekhnologii tsementirovaniia bokovykh stvolov i skvazhin malogo diametra [Improving the technology of cementing sidetracks and small-diameter wells]. Stroitel'stvo neftianykh $i$ gazovykh skvazhin na sushe i more, 2007, no. 3, pp. 34-38.

22. Taipova V.A., Shaidullin A.A., Shamsutdinov M.F. Gorizontal'nye skvazhiny i gidrorazryv v povyshenii effektivnosti razrabotki neftianykh mestorozhdenii na primere NGDU "AZNAKAUVSKNEFT"” PAO "TATNEFT"' [Horizontal wells and hydraulic fracturing in increasing the efficiency of oil field development using the example of NGDU "AZNAKAUVSKNEFT" PJSC "TATNEFT"”]. Georesursy, 2017, vol. 19, no. 3, pp. 198-203.

23. Zaitsev R.A., Martiushev D.A. Ekspluatatsiia skvazhin s gorizontal'nym okonchaniem v razlichnykh geologo-fizicheskikh usloviiakh (na primere mestorozhdenii Permskogo kraia) [Operating experience with a horizontal wells in various geological and physical conditions (for example Perm edge fields)]. Burenie i neft', 2019, no. 3, pp. 42-48.

24. Martiushev D.A. Podkhod k opredeleniiu proizvoditel'nosti skvazhin $\mathrm{V}$ treshchinno-porovykh kollektorakh Verkhnego Prikam'ia [The lead up to determining the productivity of wells fractured porous type reservoirs of the Upper Kama region]. Burenie $i$ neft', 2015, no. 2, pp. 44-46.

25. Zagrebel'nyi E.V., Martynov M.E., Kuznetsov S.V., Kovalenko I.V., Nartymov V.S., Ovcharenko Iu.V. Opredelenie optimal'nogo tipa zakanchivaniia gorizontal'noi skvazhiny i sposoba vyvoda ee na rezhim na primere razrabotki plasta $\mathrm{PK}_{1-3}$ VostochnoMessoiakhinskogo mestorozhdeniia [Determination of the optimum type of completion and method of outputting horizontal well on the regime on the example of the layer Pk1-3 of Vostochno-Messoyakhskoye field]. Neftianoe khoziaistvo, 2017, no. 5, pp. $40-43$.

26. Sitnikov A.N. Optimal'naia sistema gorizontal'nykh skvazhin s mnogostadiinym gidrorazryvom plasta pri razrabotke zalezhi na uprugom rezhime [Optimal multiple-fractured horizontal well 
pattern for depletion drive reservoirs]. Neftianoe khoziaistvo, 2017, no. 4, pp. 68-71.

27. Iurova M.P. Rol' gorizontal'nykh skvazhin pri razrabotke nizkopronitsaemykh, neodnorodnykh kollektorov [The Role of Horizontal Wells when Developing Low-Permeable, Heterogeneous Reservoirs]. Georesursy, 2017, vol. 19, no. 3, pp. 209-215.

28. Martiushev D.A., Iliushin P.Iu. Ekspressotsenka vzaimodeistviia mezhdu dobyvaiushchimi i nagnetatel'nymi skvazhinami na turne-famenskoi zalezhi Ozernogo mestorozhdeniia [Express assessment of the interaction between the production and injection wells in the tournaisian-famennian deposits of ozernoe field]. Vestnik Permskogo natsional'nogo issledovatel'skogo politekhnicheskogo universiteta. Geologiia. Neftegazovoe i gornoe delo, 2016, vol. 15, no. 18 , pp. 33-41.

29. Martiushev D.A., Mordvinov V.A. Izmenenie debita skvazhin neftegazokondensatnogo mestorozhdeniia pri snizhenii plastovykh i zaboinykh davlenii [Productivity of wells at oil and gas field while reducing the bottomhole and formation pressure]. Neftianoe khoziaistvo, 2014, no. 1, pp. 67-69.

30. Mordvinov V.A., Martiushev D.A., Chernykh I.A., Puzikov V.I. Otsenka parametrov plasta i produktivnosti skvazhin pri ego razrabotke na estestvennom rezhime [Evaluation of formation characteristics and wells productivity under primary oil recovery]. Neftianoe khoziaistvo, 2014, no. 6, pp. 31-33.

31. Iakupov R.F., Mukhametshin V.Sh., Khakimzianov I.N., Trofimov V.E. Optimizatsiia vyrabotki zapasov iz vodoneftianykh zon gorizonta D3PS Shkapovskogo neftianogo mestorozhdeniia s pomoshch'iu gorizontal'nykh skvazhin [Optimization of reserve production from water oil zones of D3ps horizon of Shkapovsky oil field by means of horizontal wells]. Georesursy, 2019, vol. 21, no. 3, pp. 55-61.

32. Fedotov I.B., Kashnikov O.Iu., Kibalenko I.A., Shevchenko O.N. Sposob analiticheskogo prognoza debita gorizontal'nykh skvazhin na mestorozhdeniiakh uglevodorodov v nizkopronitsaemykh plastakh-kollektorakh na primere mestorozhdeniia imeni V.N. Vinogradova [A method of analytic prediction of horizontal wells flowrates of hydrocarbon fields located in low-permeable formations-collectors on the example of V.N. Vinogradov field]. Geologiia, geofizika i razrabotka neftianykh $i$ gazovykh mestorozhdenii, 2018, no. 4, pp. 32-39.

33. Yanyong Wang, Shaoran Ren, Liang Zhang. Mechanistic simulation study of air injection assisted cyclic steam stimulation through horizontal wells for ultraheavy oil reservoirs. Journal of Petroleum Science and Engineering, 2019, vol. 172, pp. 209-216.

34. Jianchun GUO, Liang TAO, Fanhui ZENG. Optimization of refracturing timing for horizontal wells in tight oil reservoirs: A case study of Cretaceous
Qingshankou Formation, Songliao Basin, NE China. Petroleum Exploration and Development, 2019, vol. 46, iss. 1, pp. 153-162.

35. Xu Shiqian, Feng Qihong, Wang Sen, Javadpour Farzam, Li Yuyao. Optimization of multistage fractured horizontal well in tight oil based on embedded discrete fracture model. Computers \& Chemical Engineering, 2018, vol. 1172, pp. 291-308.

36. Kadyrov R.R., Nizaev R.Kh., Iartiev A.F., Mukhametshin V.V. Ogranichenie vodopritoka v gorizontal'nykh skvazhinakh na mestorozhdeniiakh s trudnoizvlekaemymi zapasami nefti [A novel water shut-off technique for horizontal wells at fields with hard-to-recover oil reserves]. Neftianoe khoziaistvo, 2017, no. 5, pp. 44-47.

37. Afanaskin I.V., Vol'pin S.G., Kolevatov A.A., Chenlenson Iu.B. Analiz raboty gorizontal'nykh skvazhin s mnogostadiinym gidrorazryvom plasta [Analysis of the operation of horizontal wells with multi-stage hydraulic fracturing]. Neftepromyslovoe delo, 2019, no. 1, pp. 44-51.

38. Morozov P.E. Modelirovanie nestatsionarnogo pritoka zhidkosti $\mathrm{k}$ mnogosektsionnoi gorizontal'noi skvazhine [Modeling of non-stationary fluid inflow to a multisectional horizontal well]. Georesursy, 2018, vol. 20, no. 1, pp. 44-50.

39. Baishev T.B. Analiz vyrabotki nizkoproduktivnykh zapasov nefti gorizonta viking (Zapadnaia Kanada) gorizontal'nymi skvazhinami s primeneniem GRP [Unconventional Oil Reserves Development in the Viking Play (Western Canada) Using Horizontal Wells and Hydraulic Fracturing]. Georesursy, 2017, vol. 19, no. 3, pp. 182-185.

40. Ibatullin R.R. Opyt razrabotki zapasov nefti v plotnykh kollektorakh Severnoi Ameriki. Gorizontal'nye skvazhiny i mnogostupenchatyi gidrorazryv [Experience in North America Tight Oil Reserves Development. Horizontal Wells and Multistage Hydraulic Fracturing].Georesursy, 2017, vol. 19, no. 3, pp. 176-181.

41. Wenchao Liu, Qitao Zhang, Weiyao Zhu. Numerical simulation of multi-stage fractured horizontal well in low-permeable oil reservoir with threshold pressure gradient with moving boundary. Journal of Petroleum Science and Engineering, 2019, vol. 178, pp. 1112-1127.

42. Ren Long, Su Yuliang, Zhan Shiyuan, Meng Fankun, Zhao Guangyuan. Fully coupled fluid-solid numerical simulation of stimulated reservoir volume (SRV)-fractured horizontal well with multi-porosity media in tight oil reservoirs. Journal of Petroleum Science and Engineering, 2019, vol. 174, pp. 757-775.

43. Nie Ren-Shi, Wang Yi-Min, Kang Yi-Li, Jia Yong-Lu. Modeling the characteristics of Bingham porous-flow mechanics for a horizontal well in a heavy oil reservoir. Journal of Petroleum Science and Engineering, 2018, vol. 171, pp. 71-81. 
44. Huang Shijun, Chen Xiao, Liu Hao, Jiang Jun, Xia Yun. Experimental and numerical study of solvent optimization during horizontal-well solvent-enhanced steam flooding in thin heavy-oil reservoirs. Fuel, 2018, vol. 22815, pp. 379-389.

45. Ngozi Akangbou H., Burby M., Nasr Gh. Effectively optimizing production of horizontal wells in homogeneous oil reservoirs. Journal of Petroleum Science and Engineering, 2017, vol. 150, pp. 128-136.

46. Hu Jinghong, Zhang Chong, Rui Zhenhua, Yu Yanlong, Chen Zhangxin. Fractured horizontal well productivity prediction in tight oil reservoirs. Journal of Petroleum Science and Engineering, 2017, vol. 151, p. $159-168$.

\section{Библиографический список}

1. Распопов А.В., Казанцев А.С., Антонов Д.В. Влияние мониторинга разработки на повышение эффективности эксплуатации нефтяных месторождений Пермского края // Нефтяное хозяйство. 2012. - № 6. - C. 58-61.

2. Воеводкин В.Л., Чертенков М.В. Новые технологии в компании «ЛУКОЙЛ»: от простого к сложному // Нефтяное хозяйство. - 2019. - № 8. C. 62-66.

3. Кравец М.3. Особенности проектирования плоских и пространственных траекторий скважин и боковых стволов // Инженер-нефтяник. - 2016. № 2. - C. 42-47.

4. Лакупчик А.В., Солянов С.А., Мавлетдинова М.Г. Ключевые особенности технологий проведения комплексной обработки призабойной зоны на горизонтальных многозабойных газоконденсатных скважинах // Геология, геофизика и разработка нефтяных и газовых месторождений. - 2019. - Т. 333, № 9. - C. 58-61.

5. Мартюшев Д.А. Лабораторные исследования кислотных составов для обработки коллекторов, характеризующихся различной карбонатностью и структурой пустотного пространства горных пород // Известия Томского политехнического университета. Инжиниринг георесурсов. - 2018. - Т. 329, № 4. C. $6-12$.

6. Yue-tian LIU Methodology for horizontal well pattern design in anisotropic oil reservoirs // Petroleum Exploration and Development. - 2008. - Vol. 35, iss. 5. - P. 619-624.

7. Yue Qiansheng, Liu Shujie, Xiang Xingjin Drilling fluid technology for horizontal wells to protect the formations in unconsolidated sandstone heavy oil reservoirs // Petroleum Exploration and Development. - 2010. - Vol. 37, iss. 2. - P. 232-236.
8. Применение новых технологических решений в области разработки на месторождениях ООО «ЛУКОЙЛ-ПЕРМЬ» / В.Л. Воеводкин, А.В. Распопов, Л.Н. Мужикова, С.А. Кондратьев // Нефтяное хозяйство. - 2012. - № 12. - С. 104-106.

9. Опыт и перспективы строительства скважин малого диаметра на месторождениях ООО «ЛУКОЙЛ-ПЕРМЬ» / В.Л. Воеводкин, Н.А. Лядова, Г.В. Окромелидзе, К.А. Мещеряков, С.В. Сунцов, Ю.В. Мальков // Нефтяное хозяйство. - 2018. № 12. - С. 98-102.

10. Бурение скважин малого диаметра как способ снижения затрат при строительстве эксплуатационных и разведочных скважин / К.А. Мещеряков, В.А. Яценко, С.Е. Ильясов, Г.В. Окромелидзе // Территория «НЕФТЕГАЗ». 2013. - № 10. - С. 62-65.

11. Результаты строительства первой многозабойной скважины малого диаметра в ПАО «ЛУКОЙЛ» / К.А. Мещеряков, Г.В. Окромелидзе, В.А. Яценко, Ю.В. Фефелов, С.В. Сунцов, Ю.В. Мальков // Нефтяное хозяйство. - 2018. № 10. - C. 47-49.

12. Тарасов А.Е., Старосветсков В.В. Оптимизация процесса геологического сопровождения бурения горизонтальных скважин на примере месторождения им. В.Н. Виноградова // Бурение и нефть. 2017. - № 7-8. - С. 61.

13. Проблемы и инновационные решения при бурении скважин малого диаметра / М.3. Тазиев, И.И. Кротков, Р.Р. Гараев, Н.С. Синчугов, Р.М. Осипов, А.И. Аслямов // Нефтепромысловое дело. - 2011. - № 9. - С. 34-38.

14. Yaqiang CHEN, Longxin MU, Jianying ZHANG, Guanghua ZHAI, Huiying ZHAI Horizontalwellinflow performance relationship in foamy heavy oil reservoirs // Petroleum Exploration and Development. 2013. - Vol. 40, iss. 3. - P. 389-393.

15. Wang H., Liao X., Zhao X. Study of tight oil reservoir flow regimes in different treated horizontal well // Journal of the Energy Institute. - 2015. Vol. 88, iss. 2. - P. 198-204.

16. Hybrid optimization technique for cyclic steam stimulation by horizontal wells in heavy oil reservoir / Jian Hou, Kang Zhou, Hui Zhao, Xiaodong Kang, Xiansong Zhang // Computers \& Chemical Engineering. - 2016. Vol. 844. - P. 363-370.

17. Junjun C., Yonggang D. Study on temperature distribution along wellbore of fracturing horizontal wells in oil reservoir // Petroleum. - 2015. - Vol. 1, iss. 4. - P. 358-365.

18. Старосветсков В.В., Кашников О.Ю. Особенности геологического сопровождения бурения горизонтальных скважин в сложно-построенных коллекторах (на примере месторождения 
им. В.Н. Виноградова // Геология, геофизика и разработка нефтяных и газовых месторождений. 2017. - № 2. - С. 43-49.

19. Киселев В.М., Кинсфатор А.Р., Бойков О.И. Прогноз оптимальных направлений горизонтальных стволов для разработки Юрубчено-Томоховского месторождения // Вестник Пермского национального исследовательского политехнического университета. Геология. Нефтегазовое и горное дело. - 2015. Т. 14, № 15 . - С. 20-27.

20. Садыков Р.Ш., Ибрагимова Г.Г, Оптимизация разработки участков верхних горизонтов скважинами малого диаметра с горизонтальным окончанием // Нефтепромысловое дело. - 2016. - № 9. - С. 58-61.

21. Ашрафьян М.О., Кривошей А.В. Совершенствование технологии цементирования боковых стволов и скважин малого диаметра // Строительство нефтяных и газовых скважин на суше и море. - 2007. - № 3. - С. 34-38.

22. Таипова В.А., Шайдуллин А.А., Шамсутдинов М.Ф. Горизонтальные скважины и гидроразрыв в повышении эффективности разработки нефтяных месторождений на примере НГДУ «АЗНАКАУВСКНЕФТЬ» ПАО «ТАТНЕФТЬ» // Георесурсы. - 2017. T. 19, № 3. - С. 198-203.

23. Зайцев Р.А., Мартюшев Д.А. Эксплуатация скважин с горизонтальным окончанием в различных геолого-физических условиях (на примере месторождений Пермского края) // Бурение и нефть. 2019. - № 3. - С. 42-48.

24. Мартюшев Д.А. Подход к определению производительности скважин в трещинно-поровых коллекторах Верхнего Прикамья // Бурение и нефть. - 2015. - № 2. - С. 44-46.

25. Определение оптимального типа заканчивания горизонтальной скважины и способа вывода ее на режим на примере разработки пласта ПК ${ }_{1-3}$ Восточно-Мессояхинского месторождения / Е.В. Загребельный, М.Е.Мартынов, С.В. Кузнецов, И.В. Коваленко, В.С. Нартымов, Ю.В. Овчаренко // Нефтяное хозяйство. - 2017. - № 5. - С. 40-43.

26. Ситников А.Н. Оптимальная система горизонтальных скважин с многостадийным гидроразрывом пласта при разработке залежи на упругом режиме // Нефтяное хозяйство. - 2017. № 4. - C. 68-71.

27. Юрова М.П. Роль горизонтальных скважин при разработке низкопроницаемых, неоднородных коллекторов // Георесурсы. - 2017. - Т. 19, № 3. C. 209-215.

28. Мартюшев Д.А., Илюшин П.Ю. Экспрессоценка взаимодействия между добывающими и нагнетательными скважинами на турне-фаменской залежи Озерного месторождения // Вестник Пермского национального исследовательского политех- нического университета. Геология. Нефтегазовое и горное дело. - 2016. - Т. 15, № 18. - С. 33-41.

29. Мартюшев Д.А., Мордвинов В.А. Изменение дебита скважин нефтегазоконденсатного месторождения при снижении пластовых и забойных давлений // Нефтяное хозяйство. - 2014. - № 1. С. $67-69$.

30. Оценка параметров пласта и продуктивности скважин при его разработке на естественном режиме / В.А. Мордвинов, Д.А. Мартюшев, И.А. Черных, В.И. Пузиков // Нефтяное хозяйство. 2014. - № 6. - С. 31-33.

31. Оптимизация выработки запасов из водонефтяных зон горизонта D3PSШкаповского нефтяного месторождения с помощью горизонтальных скважин / Р.Ф. Якупов, В.Ш. Мухаметшин, И.Н. Хакимзянов, В.Е. Трофимов // Георесурсы. 2019. - T. 21, № 3. - С. 55-61.

32. Федотов И.Б., Кашников О.Ю., Кибаленко И.А., Шевченко О.Н. Способ аналитического прогноза дебита горизонтальных скважин на месторождениях углеводородов в низкопроницаемых пластах-коллекторах на примере месторождения им. В.Н. Виноградова // Геология, геофизика и разработка нефтяных и газовых месторождений. - 2018. - № 4. C. 32-39.

33. Yanyong Wang, Shaoran Ren, Liang Zhang Mechanistic simulation study of air injection assisted cyclic steam stimulation through horizontal wells for ultra-heavy oil reservoirs // Journal of Petroleum Science and Engineering. - 2019. Vol. 172. - P. 209-216.

34. Jianchun GUO, Liang TAO Fanhui ZENG Optimization of refracturing timing for horizontal wells in tight oil reservoirs: A case study of Cretaceous Qingshankou Formation, Songliao Basin, NE China // Petroleum Exploration and Development. - 2019. Vol. 46, iss. 1. - P. 153-162.

35. Optimization of multistage fractured horizontal well in tight oil based on embedded discrete fracture model / Shiqian Xu, Qihong Feng, Sen Wang, FarzamJavadpour, Yuyao Li // Computers \& Chemical Engineering. - 2018. - Vol. 1172. - Р. 291-308.

36. Ограничение водопритока в горизонтальных скважинах на месторождениях с трудноизвлекаемыми запасами нефти / Р.P. Кадыров, Р.Х. Низаев, А.Ф. Яртиев, В.В. Мухаметшин // Нефтяное хозяйство. - 2017. - № 5. - С. 44-47.

37. Анализ работы горизонтальных скважин с многостадийным гидроразрывом пласта / Афанаскин И.В., Вольпин С.Г., Колеватов А.А., Ченленсон Ю.Б. // Нефтепромысловое дело. - 2019. - № 1. C. $44-51$.

38. Морозов П.Е. Моделирование нестационарного притока жидкости к многосекционной горизон- 
тальной скважине // Георесурсы. - 2018. - Т. 20, № 1. C. $44-50$.

39. Баишев Т.Б. Анализ выработки низкопродуктивных запасов нефти горизонта викинг (Западная Канада) горизонтальными скважинами с применением ГРП // Георесурсы. - 2017. - Т. 19, № 3. - С. 182-185.

40. Ибатуллин Р.Р. Опыт разработки запасов нефти в плотных коллекторах Северной Америки. Горизонтальные скважины и многоступенчатый гидроразрыв // Георесурсы. - 2017. - Т. 19, № 3. C. 176-181.

41. Wenchao Liu, Qitao Zhang, Weiyao Zhu Numerical simulation of multi-stage fractured horizontal well in low-permeable oil reservoir with threshold pressure gradient with moving boundary // Journal of Petroleum Science and Engineering. 2019. - Vol. 178. - P. 1112-1127.

42. Fully coupled fluid-solid numerical simulation of stimulated reservoir volume (SRV)-fractured horizontal well with multi-porosity media in tight oil reservoirs / Long Ren, Yuliang Su, Shiyuan Zhan, Fankun Meng, Guangyuan Zhao // Journal of Petroleum
Science and Engineering. - 2019. - Vol. 174. P. 757-775.

43. Modeling the characteristics of Bingham porous-flow mechanics for a horizontal well in a heavy oil reservoir / Ren-Shi Nie, Yi-Min Wang, Yi-Li Kang, Yong-Lu Jia // Journal of Petroleum Science and Engineering. - 2018. - Vol. 171. P. 71-81.

44. Experimental and numerical study of solvent optimization during horizontal-well solvent-enhanced steam flooding in thin heavy-oil reservoirs / Shijun Huang, Xiao Chen, Hao Liu, Jun Jiang, Yun Xia // Fuel. - 2018. - Vol. 22815. - P. 379-389.

45. Ngozi Akangbou H., Burby M., Nasr Gh. Effectively optimizing production of horizontal wells in homogeneous oil reservoirs // Journal of Petroleum Science and Engineering. - 2017. - Vol. 150. P. 128-136.

46. Fractured horizontal well productivity prediction in tight oil reservoirs / Jinghong Hu, Chong Zhang, Zhenhua Rui, Yanlong Yu, Zhangxin Chen // Journal of Petroleum Science and Engineering. 2017. - Vol. 151. - P. 159-168.

Please cite this article in English as:

Zaitcev R.A., Raspopov A.V. A practice of development of Perm Krai fields with horizontal wells. Perm Journal of Petroleum and Mining Engineering, 2020, vol.20, no.2, pp.182-191. DOI: 10.15593/2224-9923/2020.2.8

Просьба ссылаться на эту статью в русскоязычных источниках следующим образом:

Зайцев Р.А., Распопов А.В. Опыт разработки месторождений Пермского края горизонтальными скважинами // Вестник Пермского национального исследовательского политехнического университета. Геология. Нефтегазовое и горное дело. 2020. - T.20, №2. - C.182-191. DOI: 10.15593/2224-9923/2020.2.8 